\title{
The Relationship Between Values, Congruence, And Innovation Capability
}

Robert C. Preziosi, (E:mail: preziosi@huizenga.nova.edu), Nova Southeastern University

Doreen J. Gooden, (E:mail: gooden@huizenga.nova.edu), Nova Southeastern University

\begin{abstract}
Some organizations are highly innovative and successful, while others are less innovative and successful. What are the conditions that are associated with innovativeness? This paper assesses values congruence as one variable which may be present in organizations whose professionals and managers report significant organizational innovativeness. The Innovation Capability Audit and the Values Analysis Worksheet were administered to a group of research participants to determine the relationship between innovation and values congruence. A correlation of - .711 was found. This indicates a significant inverse relationship between the two variables being measured, innovation, and values congruence.
\end{abstract}

\section{Introduction}

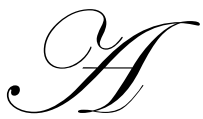

s organizations seek to become more competitive, it has been recognized that values congruence is a key factor for success. Meglino, Ravlin, and Adkins (1989) found that when employees' values are congruent with the values of the employing organizations, there are beneficial effects on outcomes to organizations. One such outcome is innovation capability. Heaps (2001) describes innovation as the process by which knowledge is translated into new products, new services or enhanced productivity through process improvement. This process has become increasingly important with the changing desires of customers, increased level of competition, and changes in technology. It would be reasonable to assume, therefore, that every organization would be interested in becoming more innovative. The questions then would be, where is this knowledge coming from to facilitate the transformation? and how is innovation encouraged in organizations? This study seeks to examine values congruence as a contributing factor to innovation in organizations.

\section{Research Questions}

This research addresses two questions:

1. Is there a relationship between values congruence and innovation capability in organizations?

2. If such a relationship exists, what is the nature of that relationship?

\section{Literature Review}

Values Congruence

Rokeach (1973) defined value as "an enduring belief that a specific mode of conduct or end-state is personally or socially preferable to an opposite or converse mode of conduct or end-state existence". According to Hersey, Blanchard, and Johnson (1996), values reflect the rights and wrongs, the do's and don'ts, and are a representation of what the organization approves and rewards and what it disapproves of and sanctions. Congruency refers to "the degree to which the needs, objectives, and/or structures of a certain component are consistent with the needs, demands, goals, objectives, and/or structures of another component" Nadler \& Tushman (1980). To ensure

Readers with comments or questions are encouraged to contact the authors via email. 
organizational success, the values of the organization and those of the employees should be congruent (Harshman \& Harshman, 1999; Posner \& Schmidt, 1993; Schweper, 1999). Crowell (1998) suggests that a group or organization is congruent when what it does is the same as what it believes. The same is true at the individual level.

Congruence (or consistency) is also said to exist when two entities are in agreement about some issues or variable. Preziosi and Barnes (1998) found a significant inverse relationship between values consistency (congruency) and human resource department orientation. Gordon, Harrington, and Preziosi (1999) found a relationship between values congruency and total quality management practices among critical care nurses. In yet another research, Preziosi and Slaoui-H (1999) found a significant relationship between values congruency and customer service management practices among hotel executives in Morocco. Preziosi and Gooden (2001) found a significant relationship between values congruence and high performance teams among executives. The more congruent the employees values are with the organization, the greater the probability that the organization acts in ways that lead to sustainability (Gordon, Harrington, and Preziosi (2000). Pohlman and Gardiner (2000) suggest that if an organization does not understand what its true value system is, attempting to implement value congruence with its' employees will be difficult.

Incongruence between personal values and those of the organization can lead to employee distrust, lower performance and productivity, reduced quality of output (Harshman \& Harshman, 1999), job dissatisfaction (Posner \& Schmidt, 1993), and increased intentions to leave (Schwepker, 1999). Thus, organizations have a significant interest in the relationship between employee values and organization values.

\section{Innovation Capability}

In June 2001 issue of Training and Development magazine, Michael Doyle, Chairman and CEO of MemeStreams suggests that "with the speed of the current U.S. economy, if a company doesn't develop an ability to innovate, it will be left behind." Researchers argue that innovativeness is the extent to which an individual is relatively earlier in adopting an innovation than other members of his or her social system. Thus, creating and maintaining access to sources of innovation which allow for opportunities in organizational learning becomes an important issue (Franko 1989).

Hadjimanolis (2000) defined capabilities as those features of the firm and managerial skills which form organizational routines and which lead to competitive advantage. Thus, he said that innovation capabilities can be considered as a "subset of organizational capabilities" where they include the capacity to understand competitor's strategies, industry evolution, and the firm's technological environment. $3 \mathrm{M}$ has consistently exhibited such capabilities and has been very successful based upon a variety of different measures of success.

Heap (2001) pointed out that "innovation increases productivity not only for firms who directly innovate, but also for firms who benefit from the "ripple effect". Thus, an entire economy can benefit. The personal computer is a perfect example. Dodgson and Rothwell (1991) found the role of management as being very important for technological innovation in small firms. Of great importance they found a high quality of leadership and a top management team with a vision for the future. According to Edvinsson (2000) because of the talent war, leaders should pay more attention to issues relating to culture and values and that new managers need to be able to capture and cultivate minds. This is foundational because the seeds of innovation are found in the minds of the people who work in organizations.

Sethi, Smith, and Whan Park (2001) found that superodinate identity is positively related to new product innovativeness and that social cohesion is negatively related to innovativeness. They also found that encouragement to take risk is positively related to new product innovativeness.

Judge, Fryxell and Dooley (1997) found that highly innovative units behaved as focused communities where members had a "family feeling" and socialized a lot. Less innovative units behaved more like traditional bureaucratic departments. They found that in the highly innovative units, the family environment created a sense of trust and caring and members of the units relied heavily on highly intrinsic rewards to recognize individual and 
group successes. Less innovative units placed emphasis on impersonal and extrinsic rewards. Pittman, Emery, and Bogianno (1982) found that workers' energies can be misdirected if the focus is too much on extrinsic rewards. Providing opportunities for intrinsic rewards on the other hand, can direct workers' energies into creative efforts. The driving force is internal, just as it is with values congruence.

Hattori and Wycoff (2002) emphasize the importance of values to innovation. They say that core values exist in all organizations. They believe that values such as learning, commitment, and people development drive innovation.

\section{Methodology}

Participants $(\mathrm{N}=115)$ were drawn from a non-traditional MBA capstone course at Nova Southeastern University. Four groups out of a possible twenty-six were chosen at random from this sample of convenience. Two sets of data were collected:

1. Participants were asked to assess their organizations and themselves on the twenty-three values of the action research tool, "Values Analysis Worksheet". A four-point Likert Scale was used with the following response options: $4=$ consistently, $3=$ often, $2=$ occasionally, and $1=$ never. The differences of the two scores for each of the twenty-three pairs of scores were summed yielding a values congruency score for each study participant. Scores ranged between 3 and 39 out of a possible range of 0-69. Lower scores indicate greater congruence.

2. Participants were asked to complete the action research tool "Innovation Capability Audit Questionnaire" consisting of fifty four questions. A six point likert scale with the responses: $1=$ To little or no extent; $2=$ To a slight extent; $3=$ To a moderate extent; $4=$ To a great extent; $5=$ To a very great extent; $6=$ Totally. A total score for each participant was determined. The higher the score, the higher the innovation capability.

A correlation coefficient was performed to determine the relationship between values congruence and innovation capability in organizations. The $\mathrm{P}$ value was also attained to determine the degree of significance for the correlation coefficient. The R squared value was also determined.

\section{Findings}

The result of the correlation coefficient was: $r=-.711$, indicating a strong, though inverse relationship between the two variables. This suggests that if there is values congruence amongst employees and the organization in which they work, then the probability of the innovative capability will be high. The $\mathrm{P}$ score was $\mathrm{P}<.01$, indicating an acceptable degree of significance for the correlation coefficient. The $\mathrm{R}$ squared value was .505 suggesting that close to $51 \%$ of the variability in innovative capability is explained by values congruence.

\section{Conclusion}

It is clear from this study that there is a relationship between values congruence and innovation capability. Other studies and theoretical papers have shown the same general stream of thought. Evidence continues to mount that values congruence is related to a number of variables of organization effectiveness.

Researchers will continue to build scientific evidence that organizations can put into practice. In a perfect world of available resources, every organization could subject itself to field studies and gain the most benefit for itself. While researchers will continue to search for universal truths, organizations that partner with researchers can provide sample populations for a large database as well as a key understanding of organization effectiveness for the individual organization. 


\section{References}

1. Crowell, D. (1998). Organizations are Relationships: A New View of Management. Nursing Management, 29 (5), 2829.

2. Dodgson, M., and Rothwell, R. (1991). Technology Strategies in Small Firms. Journal of General Management, 17 (1), 45-55.

3. Doyle, M. (2001). Definitely not Mainstream. In Weiss, R. P (2001). Eye of Innovation. Training and Development Magazine,_ASTD, June 2001, 29-44.

4. Edvinsson, L. (2000). Some perspectives on intangibles and intellectual capital 2000. Journal of Intellectual Capital, 1 (1), 12-15.

5. Franko, L. (1989). Global Corporate Competition: Who's Winning, Who's Losing, and the R \& D Factor as one Reason Why. Strategic Management Journal, 10 (5), 449-474.

6. Francis, D. (1998). Innovation Capability Audit in The 1998 Annual Volume 2 Consulting. San Francisco: JosseyBass/Pfeiffer, 113-129.

7. Gordon, J., Harrington, W.J., and Preziosi, R.C. (2000). Perception of the Relationship between Values Congruency and Organization Sustainability in Dar-El, E., and others, Productivity and Quality Management Frontiers - IX, West Yorkshire, England: MCB University Press.

8. Hadjimanolis, A. (2000). A Resource-based View of Innovativeness in Small Firms. Technology Analysis and Strategic Management, 12 (2), 263-281.

9. Hersey, P., Blanchard, K., and Johnson, D. (1996). Management of Organizational Behavior Utilizing Human Resources, Upper Saddle River, NJ: Prentice-Hall Inc.

10. Harshman, E. and Harshman, C. (1990). Communicating with employees: Building on an ethical foundation. Journal of Business Ethics, 19 (1), 3-19.

11. Hattori, R., and Wycoff, J. (2002). Innovation DNA. Training and Development Magazine, ASTD. , Jan. 2002, $24-30$.

12. Heaps, J. (2001). The Role of National Productivity Organizations in facilitating Innovation. Management Services, Dec. 2001, 18- 22.

13. Judge, W., Fryxell, G., and Dooley, R. (1997). The New Task of R \& D Management: Creating Goal-Directed Communities for Innovation. California Management Review, 39 (3), 72-85.

14. Meglino, B.M., Ravlin, E.C., and Adkins, C. (1989). A Work Values Approach to Corporate Culture: A Field Test of the Value Congruence Process and Its Relationship to Individual Outcomes, Journal of Applied Psychology, 74 (3), 424-432.

15. Nadler, D.A. and Tushman, M. (1980). Organizational Dynamics, 9 (2), 35-48.

16. Pittman, T., Emery, J. and Boggiano, A. (1982). Intrinsic and Extrinsic Motivational Orientations: Rewarding Induced Changes in Preferences for Complexity. Journal of Personality and Social Psychology, 42 (5), 789-797.

17. Pohlman, R., and Gardiner, G. (2000) Value Driven Management. New York: Amacom.

18. Posner, B. Z. (1992). Person-Organization Values Congruence: No support for Individual Differences as a Moderating Influence. Human Relations, 45 (4), 531-542.

19. Posner, B.Z. Kouzes, J.M., \& Schmidt, W.H. (1985). Shared values make a difference: An empirical test of corporate culture. Human Resource Management, 24 (3), 293-309.

20. Posner, B.Z. \& Schmidt, W.H. (1993). Values Congruence and differences between the interplay of personal and organizational value systems. Journal of Business Ethics, 12, (5), 341-347.

21. Preziosi, R.C., and Barnes, F.B. (1998). The Relationship Between Values Consistency and HR'S Partnership Orientation. Paper presented at Institute for Behavior and Applied Management Conference, Orlando, FL Proceedings.

22. Preziosi, R.C., and Gooden, D.J. (2001). The Relationship between Values Congruence and High Performance Teaming. Paper presented at the Center for the Study of Work Teams, University of Texas.

23. Preziosi, R.C., and Harrington, W. (1998). How consistent are your values with the organizations? The 1998 Training and Performance Sourcebook, New York: McGraw-Hill, 177-185.

24. Preziosi, R.C., and Slaoui-H, R.K. (1999). The Relationship between Values Congruency and Customer Services Management Practices among Hotel Managers in Morocco in Edosomwan, J. A. Customer Satisfaction Management Frontiers - III 1999, Virginia, USA.

25. Rokeach, M. (1973). The Nature of Human Values, New York, The Free Press.

26. Schwepker, C. (1999). Research Note: The relationship between ethical conflict, organizational commitment, and turnover intentions in the salesforce. The Journal of Personal Selling \& Sales Management, 19 (1), 43-49.

27. Sethi, R., Smith, D., and Whan Park, C. (2001). Cross-functional Product Development Teams, Creativity, and the Innovativeness of New Consumer Products. Journal of Marketing Research, 38 (1), 73-85. 